Abstracta Iranica Abstracta Iranica

Revue bibliographique pour le domaine irano-aryen

Volume 23 | 2002

Comptes rendus des publications de $\mathbf{2 0 0 0}$

\title{
Bā tarāne-ye bārān, zendegī va še 'r-e Golčīn Gïlānī. Tehrān, Tāâtet, 1379/2000, 282 p. [Avec les chants de la pluie, vie et œuvre du poète G. Gìlānī]
}

\section{Christophe Balaÿ}

\section{(2) OpenEdition}

1 Journals

\section{Édition électronique}

URL : http://journals.openedition.org/abstractairanica/35848

DOI : 10.4000/abstractairanica.35848

ISSN : 1961-960X

Éditeur :

CNRS (UMR 7528 Mondes iraniens et indiens), Éditions de l'IFRI

\section{Édition imprimée}

Date de publication : 15 mai 2002

ISSN : 0240-8910

\section{Référence électronique}

Christophe Balaÿ, «Bā tarāne-ye bārān, zendegī va še'r-e Golčīn Gīlānī. Tehrān, Tạaleț, 1379/2000, 282 p. [Avec les chants de la pluie, vie et œuvre du poète G. Gïlāni] », Abstracta Iranica [En ligne], Volume 23 | 2002, document 294, mis en ligne le 08 février 2010, consulté le 25 septembre 2020. URL : http:// journals.openedition.org/abstractairanica/35848; DOI : https://doi.org/10.4000/abstractairanica. 35848

Ce document a été généré automatiquement le 25 septembre 2020.

Tous droits réservés 


\title{
Bā tarāne-ye bārān, zendegī va še $e^{\prime}-e$ Golčìn Gïlānī. Tehrān, Tālet, 1379/2000, 282 p. [Avec les chants de la pluie, vie et œuvre du poète G. Gīlānì]
}

\author{
Christophe Balaÿ
}

Majdoddīn FaHrā̄̄î̄, poète né à Rašt en 1288/1909 dans une famille de lettrés. Après ses études élémentaires à Rašt, le jeune FaHrā'î poursuit ses études à Téhéran à l'école Sīrūs puis à l'école Polytechnique. Il est le condisciple de Dِabịhollāh Șafā et l'élève de Vahịid Dastgerdī. Il suit le cursus universitaire à l'Ecole Normale puis fait partie du groupe d'étudiants boursiers de l'Etat envoyés en France puis en Angleterre. Le jeune Golčīn commence par des études d'anglais et de littérature, mais courageusement et à l'encontre de son gouvernement, il se tourne vers la médecine. Il traverse toute la seconde guerre mondiale, en restant à Londres où il est diplômé de médecine en 1947. Golčìn ne fut pas très heureux en amour : trois mariages dont le premier forcé avec une cousine à 13 ans. Il meurt à Londres en 1972 d'une leucémie. Le présent ouvrage comporte une petite biographie et une étude de l'œuvre poétique. G.G. y est présenté comme un des précurseurs de še r re now bien que sa première période (iranienne) fût classicisante. La deuxième période - anglaise - se tourne peu à peu vers le modernisme avec la publication de Bārān en 1940. Son premier recueil Nahofte parait à Londres en 1948. La poésie de G.G. paraît aussi dans la presse. Ses thèmes sont l'enfance du poète, la guerre, la nature, la vie et le mort. Les périodes finales (50-70) sont moins productives mais influentes sur les milieux poétiques iraniens: H. Ebtehāj, šāmlū, FarroHzzād et bien d'autres ont subi cette influence. La poésie de G.G. est une poésie simple où les sentiments et les souvenirs prédominent. Après l'étude thématique et celle des techniques poétiques, l'A. offre une anthologie de la poésie de Golčĩn plus 
quelques traductions en anglais (on ne dit pas si elles sont de la main du poète ou non) et une bonne bibliographie.

INDEX

Thèmes : 11.1.2. Littérature persane moderne

\section{AUTEURS}

\section{CHRISTOPHE BALAŸ}

IFRI - Téhéran 